\title{
Mussel biodeposition in an estuary in southern Chile
}

\author{
E. Jaramillo, C. Bertrán, A. Bravo \\ Instituto de Zoología, Universidad Austral de Chile, Valdivia, Chile
}

\begin{abstract}
Temporal variability in biodeposit production by Choromytilus chorus (Molina) and Mytilus chilensis (Hupe) was studied from February 1989 to January 1990 in the Queule River Estuary, southern Chile. Biodeposits were collected monthly from PVC cylinders containing $C$. chorus or $M$. chilensis and analyzed for total dry weight, inorganic and organic weight and organic carbon and nitrogen content. Water characteristics (temperature, sálinity, oxygen, chlorophyll $a$, seston) were also measured at each sampling period. The highest biodeposition rates were calculated during spring and summer months; from October until January sedimentation and mussel biodeposition rates were similar. During this period the highest temperature and water salinities occurred, as well as one of the 2 chlorophyll a peaks observed during the study. The lowest biodeposition rates occurred during winter months, when temperature and water salinities were lowest and turbidity of the water was at its highest. Mean annual biodeposition rate of $C$. chorus was $271 \mathrm{~g}$ total dry weight (DW) $\mathrm{m}^{-2} \mathrm{~d}^{-1}$, with 212 and $59 \mathrm{~g}$ DW $\mathrm{m}^{-2} \mathrm{~d}^{-1}$ for the inorganic and organic fractions, respectively. Mean annual biodeposition of $M$. chilensis was $234 \mathrm{~g}$ total DW m $\mathrm{m}^{-2} \mathrm{~d}^{-1}$, with 184 and $49 \mathrm{~g} \mathrm{DW} \mathrm{m}^{-2} \mathrm{~d}^{-1}$ for the inorganic and organic fractions. Mean annual sedimentation rate was $553 \mathrm{~g}$ total DW m-2 $\mathrm{d}^{-1}$, with 458 and $95 \mathrm{~g} \mathrm{DW} \mathrm{m}^{-2} \mathrm{~d}^{-1}$ for the inorganic and organic fractions, respectively. Biodeposits of $C$. chorus averaged annually $6.4 \%$ carbon and $0.3 \%$ nitrogen, with a $C / N$ ratio of 40.8 . Biodeposits of $M$. chilensis averaged $6.0 \%$ carbon and $0.4 \%$ nitrogen, with a $\mathrm{C} / \mathrm{N}$ ratio of 21.4 . Naturally sedimented material averaged annually $5.5 \%$ organic carbon and $0.5 \%$ organic nitrogen, with a $\mathrm{C} / \mathrm{N}$ ratio of 13.6 .
\end{abstract}

\section{INTRODUCTION}

Sedimentation removes suspended material from the water column. Similarly, suspension feeder invertebrates, such as mussels, oysters, barnacles, copepods and tunicates, remove particles, repackage them and return them to the water column as faecal pellets. Thus, faecal pellet production may contribute significantly to the amount of suspended particles in the water column (Moore 1931, Haven \& Morales-Alamo 1968, 1972, Young 1971, Kraeuter 1976, Kautsky \& Evans 1987). Faecal pellets eventually settle, a process known as biodeposition (Haven \& Morales-Alamo 1966); this increases settling rates of the original fine particles composing the pellets (Haven \& Morales-Alamo 1968, Hawley 1982). After deposition, faecal pellets may contribute to physico-chemical and biological changes in the bottom sediments, as described by Dahlbäck \& Gunnarsson (1981).

The importance of biodeposition by suspension feeders will be proportional, among other things, to their abundances, the extent of their distributions, and the temporal variability in their biodeposition rates. For bivalves, these rates may be adversely affected by abiotic factors such as water temperature (Tsuchiya 1980) and low salinities, which result in valve closure (e.g. Hand \& Stickle 1977, Shumway 1977), reduced feeding activity (Bohle 1972, Widdows 1985, Navarro 1988) and, consequently, low biodeposition rates (e.g. Tsuchiya 1980). On the other hand, higher food concentrations may enhance suspension feeding and thus biodeposition rates (e.g. Tenore \& Dunstan 1973b).

The mussels Choromytilus chorus (Molina) and Mytilus chilensis (Hupe) are the most distinctive suspension feeders of the subtidal soft bottoms in the Queule River Estuary $\left(39^{\circ} 26^{\prime} \mathrm{S}\right)$ in southern Chile. In some artificially seeded areas of this estuary, mussel densities may be as high as 250 to 300 adult ind. $\mathrm{m}^{-2}$. It is therefore reasonable to expect that in the waters adjacent to these high-density areas, resuspended biodeposits will form a significant component of the total particle load in the water column (e.g. Smaal et al. 1986). Thus, the aim of this study was to measure the field biodeposition rates of $C$. chorus and $M$. chilensis 
and to compare those rates with the natural sedimentation rate in this estuary. We also studied the temporal variability in abiotic characteristics and food concentrations in the water column, analyses which allowed us to speculate on the causes that ultimately contribute to variability in the biodeposition rates.

\section{MATERIAL AND METHODS}

Water column. The study site was located in the central part of the Queule River Estuary (Fig. 1) at a depth of about $4 \mathrm{~m}$. At monthly intervals from February 1989 to January 1990 water samples were taken during low and high tides. The samples were collected at the surface $(0.5 \mathrm{~m}$ deep) and bottom $(0.5 \mathrm{~m}$ above bottom) with a Ruttner sampler to determine temperature, salinity, and oxygen, chiorophyll a and seston concentrations. Water temperature was determined with a mercury thermometer accurate to $\pm 0.1^{\circ} \mathrm{C}$ and in- stalled in the same bottle. Salinity values were calculated through conductivity measurements obtained from a WTW-LBR40 conductivity meter as well as from a list of formulas presented by Bennett (1976). Oxygen determinations were carried out using the iodometric Winkler method (Maucha 1932).

The amount of food potentially available to mussels was determined by analyses of chlorophyll a. Water samples (0.5 l each) were filtered through $4.5 \mu \mathrm{m}$ pore Millipore glass-fiber filters, which were then stored in $95 \%$ acetone at 3 to $4{ }^{\circ} \mathrm{C}$ in the dark. Later on, the acetone extracts were centrifuged and measured on a Shimadzu spectrophotometer (model UV-150-02) using a $1 \mathrm{~cm}$ pyrex cell. Samples were measured before and after acidification at 750 and $665 \AA$. Chloropyhll a concentrations were calculated and expressed as mg pigment $\mathrm{m}^{-3}$ (Strickland \& Parsons 1972). Additional 0.51 water samples were filtered through pre-weighed and pre-combusted $\left(550^{\circ} \mathrm{C}, 15 \mathrm{~min}\right) 4.5 \mathrm{um}$ pore Millipore glass-fiber filters for measurement of seston con-

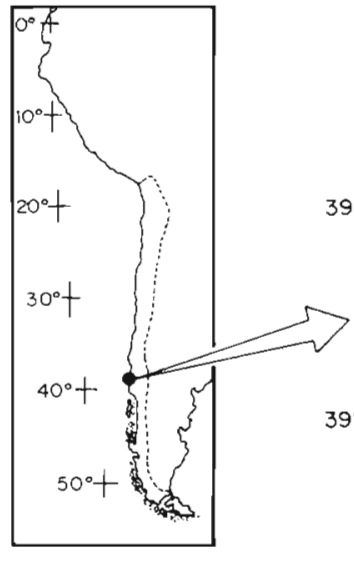

$39^{\circ} 29^{\prime}$
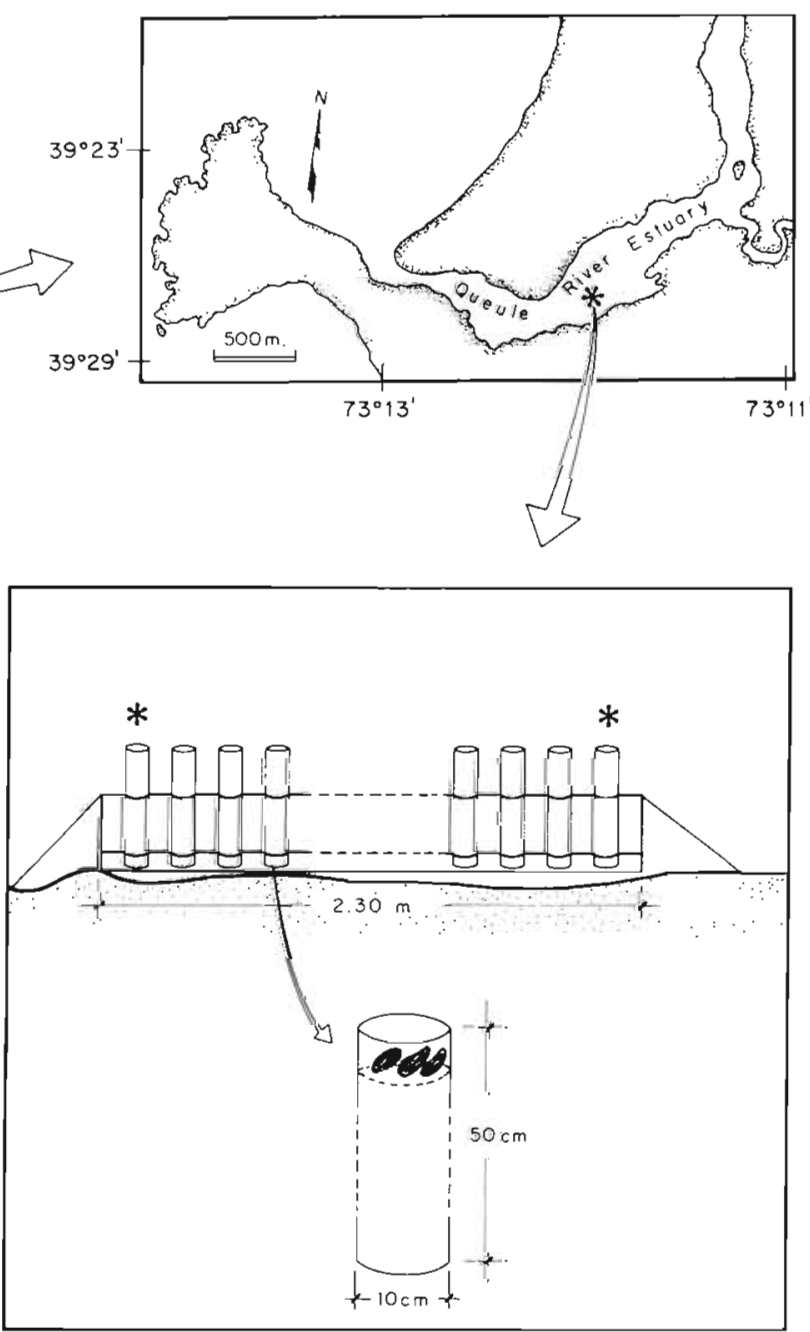

Fig. 1. Study area at Queule River Estuary, southern Chile, and diagram of rack for holding PVC cylinders for in situ determinations of natural sedimentation and mussel biodeposition. The 2 cylinders with asterisks were not used in this study, since they were affected by different flow characteristics relative to the others 
centrations. After filtration, filters were rinsed with $250 \mathrm{ml}$ distilled water to remove salts, dried at $60^{\circ} \mathrm{C}$ for $24 \mathrm{~h}$ and then combusted at $550^{\circ} \mathrm{C}$ for $15 \mathrm{~min}$ for particulate organic material determinations.

Natural sedimentation and biodeposition rates. Natural sedimentation and rates of biodeposition by Choromytilus chorus and Mytilus chilensis were examined monthly from February 1989 to January 1990, closely following the methods used by Kautsky \& Evans (1987), whereby a rack with PVC cylinders (10 $\mathrm{cm}$ diameter, $50 \mathrm{~cm}$ height) was installed by divers on the bottom (Fig. 1). The experimental design involved 3 treatments with 5 replicates each. One treatment contained living $C$. chorus; another one, living $M$. chilensis; the third, a mixture of mussel shells of both species, held together with wire (i.e. dead mussels). This last treatment served as a control, since those cylinders collected only the naturally sedimenting particles. Each replicate cylinder contained 3 mussels, either alive or dead, supported at the top of the cylinder by a net ( $20 \mathrm{~mm}$ mesh) (Fig. 1). The density and size of experimental mussels ( 75 to $90 \mathrm{~mm}$ shell length) were similar to those of mussels found in the surrounding sublittoral beds (250 to 300 ind. $\mathrm{m}^{-2}$ ).

Biodeposition rates of Choromytilus chorus and Mytilus chilensis were determined as the amount of material collected from each cylinder holding living mussels minus the mean sedimentation rate calculated for the cylinders holding dead mussels. After $2 \mathrm{~d}$, the cylinders were retrieved from the bottom by divers and taken to the laboratory, where they were allowed to stand for $5 \mathrm{~h}$ without the experimental mussels to allow settlement of suspended matter. Later on, excess water was siphoned off and the collected material rinsed several times with distilled water to remove salts. The material was then dried at $60^{\circ} \mathrm{C}$ for $4 \mathrm{~d}$. A portion of this dried sediment was used for particulate organic material determinations (combustion at $550^{\circ} \mathrm{C}$ for $4 \mathrm{~h}$ ), while another one was used for organic carbon and organic nitrogen determinations. Organic carbon was determined using an oxidation technique with a potassium dichromate/sulphuric acid mixture, followed by colorimetric reading on a Shimadzu spectrophotometer (Model UV-150-02 model) (Riehm \& Ulrich 1954). Organic nitrogen was analyzed as $\mathrm{NH}_{4}-\mathrm{N}$ after Kjeldahl combustion with sulphuric acid (Schlichting \& Blume 1966).

\section{RESULTS}

\section{Water characteristics}

Figs. $2 \& 3$ show the temporal variability in water characteristics at the study site, and the variability in rainfall $5 \mathrm{~km}$ south of the Queule River Estuary. Water temperature followed a typical seasonal pattern, with the lowest values registered from early winter (June) to early spring (September). Thus, during this period, temperatures dropped down to $10-11^{\circ} \mathrm{C}$ as compared with summer highs of nearly $20^{\circ} \mathrm{C}$. From October to January, water temperatures, at both low and high tide, were slightly higher at the surface. Salinity followed a pattern similar to that of temperature, i.e., the lowest values occurred from June through September, the period in which the most rainfall occurred (Fig. 3). Thus, water salinity and rainfall values were significantly $(\mathrm{p}<0.05)$ and highly correlated $(\mathrm{r}=0.67$ to 0.89$)$ for all analyses carried out (i.e. surface and bottom waters during low and high tides). From June to September, salinities were lowest at the surface 0.5 to $2.1 \%$ ) , even when low values were also measured in the bottom waters during low tide. Water salinity values were higher in the bottom waters (up to $28.5 \%$ ), except for the period February to June, when salinities of surface and bottom waters were similar during high tides (Fig. 2). Generally, oxygen concentrations did not vary much during the study period; moreover, these concentrations were quite similar between low and high tides (Fig. 2).

The cycle of the phytoplankton standing crop, measured as chlorophyll $a \mathrm{~m}^{-3}$, displayed peak values during summer and autumn months, while from winter through late spring (July to November) pigment concentration was at a minimum (Fig. 4). During low tides, chlorophyll a values were quite similar in surface and bottom waters. On the other hand, during the high tides between February and March, pigment concentrations in surface waters were higher than those in bottom waters. During high tide in April the chlorophyll a concentration in surface waters was the highest (243 $\mathrm{mg} \mathrm{m}^{-3}$ ) ever recorded during the study period.

Fig. 5 shows the temporal fluctuation of particulate material (seston) in water. A seasonal trend was clearly seen during low tide, in both surface and bottom waters, which had similar seston concentrations. During this tidal stage, total particulate material (TPM) peaked during winter (June through August), reaching values up to between 15 and $17 \mathrm{~g} \mathrm{l}^{-1}$. The temporal variability in TPM was better accounted for by the variability in particulate inorganic material (PIM) $\left(\mathrm{R}^{2}=\right.$ 0.97 and 0.98 for surface and bottom waters, respectively) than by that in particulate organic material (POM) $\left(\mathrm{R}^{2}=0.73\right.$ and 0.85 for surface and bottom waters, respectively). The only apparent peak in TPM registered during high tides occurred during June (Fig. 5). During the first months of the study period, values of TPM, PIM and POM at high tide were similar in surface and bottom waters, while during spring (September to 
low tide
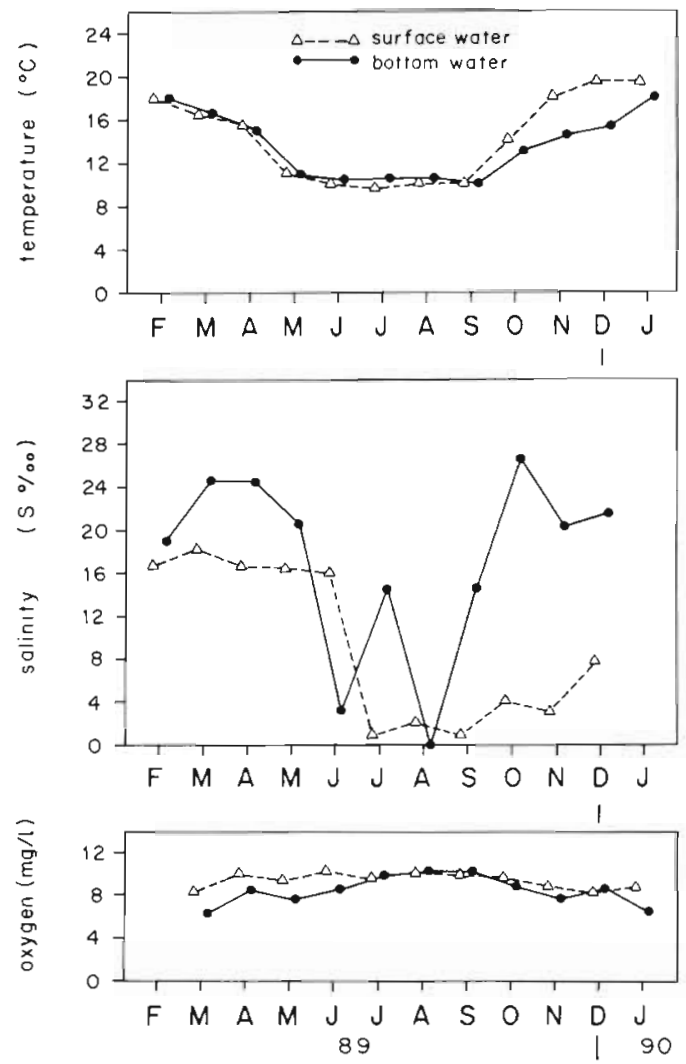

high tide
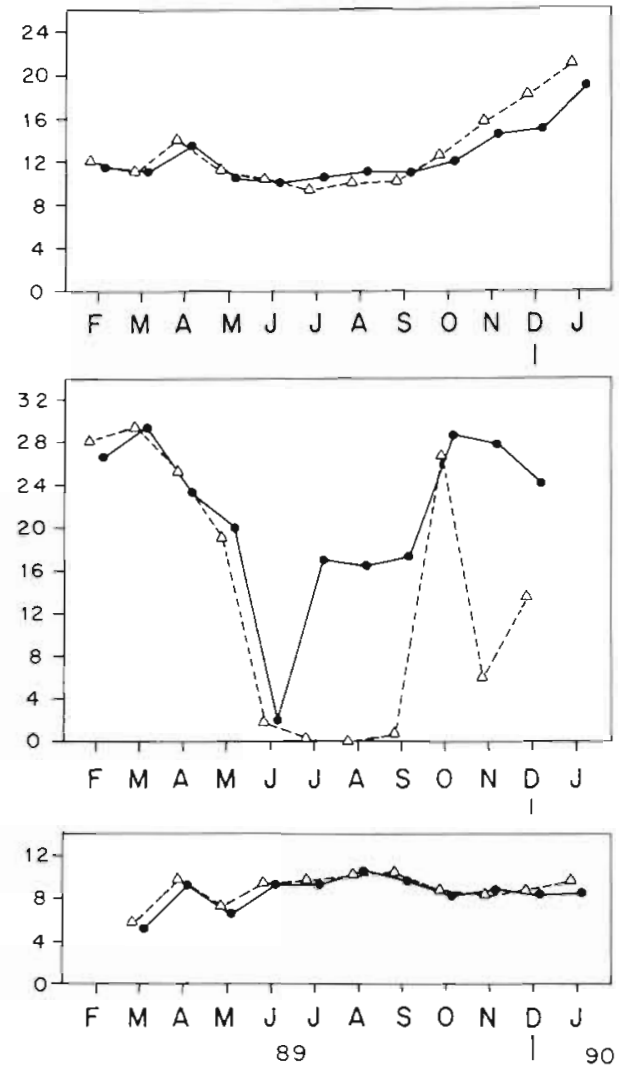

Fig. 2. Temporal variability in temperature, salinity and oxygen concentrations in surface and bottom waters at the study site in 1989 and 1990

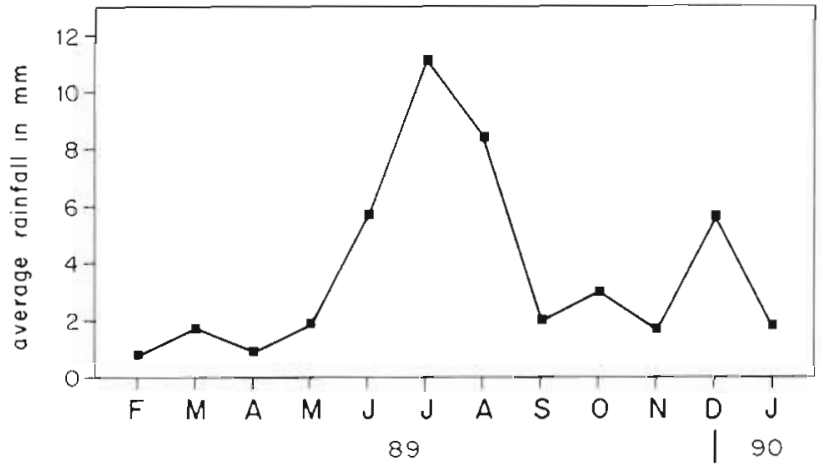

Fig. 3. Temporal variability in average rainfall at the meteorological station of the Universidad Austral de Chile in Mehuín (ca $35 \mathrm{~m}$ above sea level), $5 \mathrm{~km}$ south of the Queule River Estuary, in 1989 and 1990

October) higher values were detected in the bottom waters. Similarly to that found during low tides, the temporal variability in TPM during high tides was better accounted for by the temporal variability in PIM $\left(\mathrm{R}^{2}=0.94\right.$ and 0.96 for surface and bottom waters, respectively) than by that in $\operatorname{POM}\left(R^{2}=0.36\right.$ and 0.21 for surface and bottom waters, respectively).

\section{Sedimentation and biodeposition rates}

Mean sedimentation and biodeposition rates of Choromytilus chorus and Mytilus chilensis are shown in Fig. 6. During most of the first half of this study (February through July), mean sedimentation rates significantly $(\mathrm{p}<0.05)$ exceeded mean biodeposition rates; from April through July, sedimentation rates increased, while biodeposition rates decreased. During the second half of the study (August through January), sedimentation rates were significantly higher than biodeposition rates during August and September, while from October through January both rates were similar. For the most part, no significant differences were found between the mean biodeposition rates of $C$. chorus and $M$. chilensis (Fig, 6).

Mean sedimentation rates varied from 223 (October) to 1269 (July) $\mathrm{g}$ dry weight (DW) $\mathrm{m}^{-2} \mathrm{~d}^{-1}$, with an annual mean of $553(\mathrm{SD}=275)$. The highest values were observed in winter (June-July), while the lowest occurred during spring (October through December) (Fig. 6). Ranges for mean biodeposition of Choromytilus chorus and Mytilus chilensis were 0.1 to $426 \mathrm{~g} \mathrm{DW}$ $\mathrm{m}^{-2} \mathrm{~d}^{-1}$ (annual mean $=271, \mathrm{SD}=111$ ) and 13 to $426 \mathrm{~g}$ 

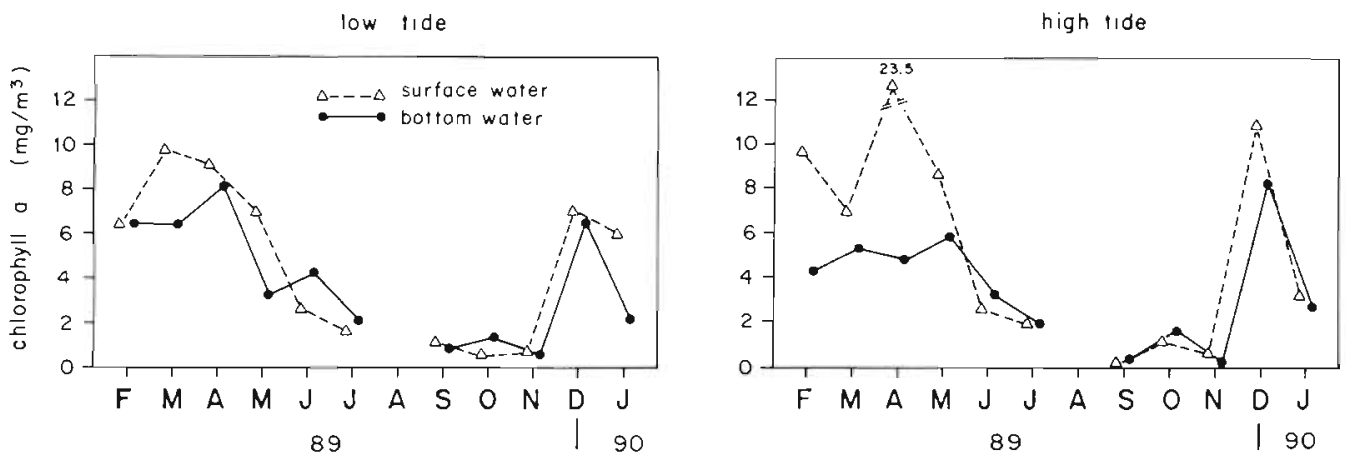

Fig. 4. Temporal variability in chlorophyll a concentration in the surface and bottom waters of the study site in 1989 and 1990
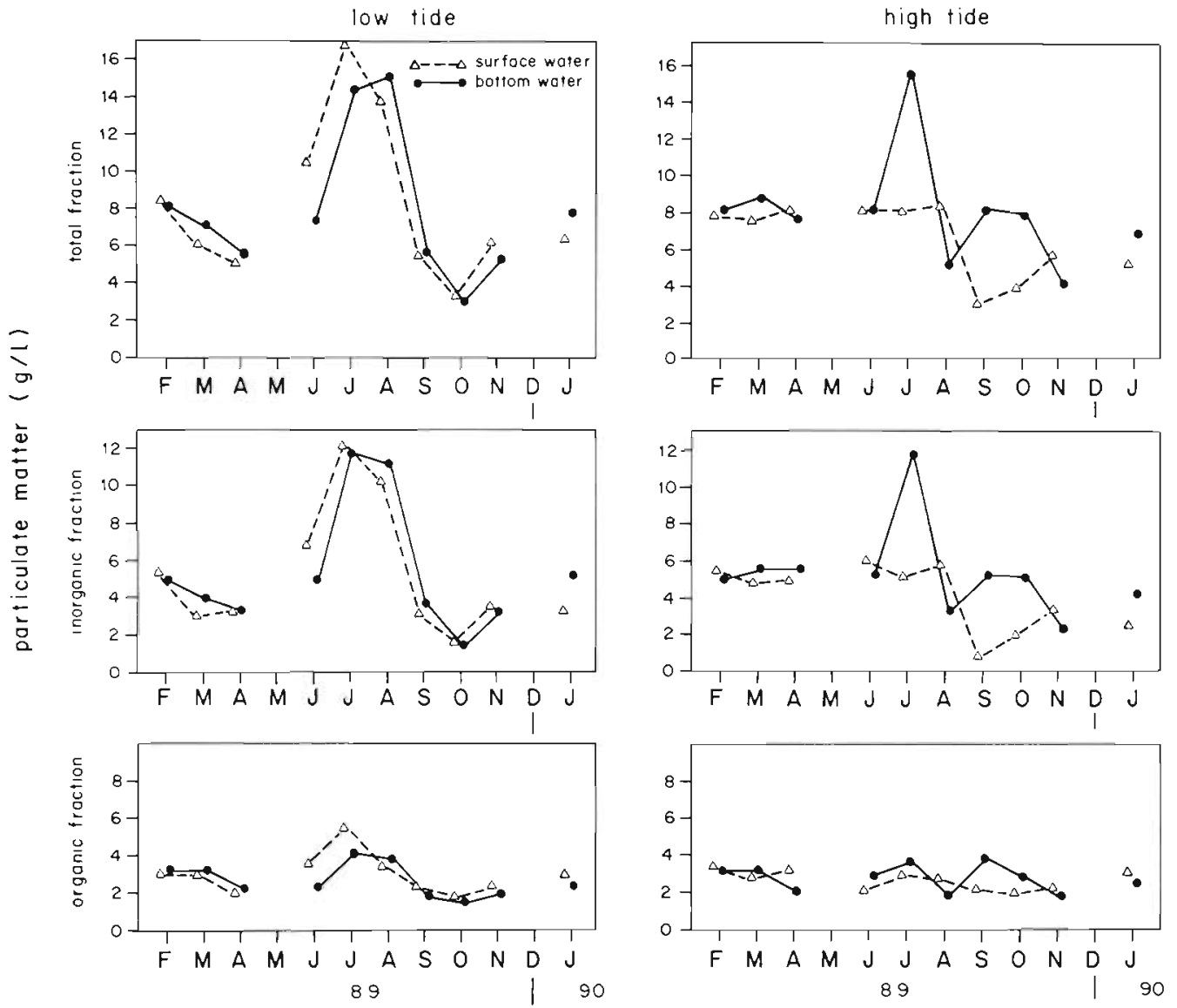

Fig. 5. Temporal variability in seston content (total and inorganic and organic fractions) of surface and bottom waters at the study site in 1989 and 1990

DW $\mathrm{m}^{-2} \mathrm{~d}^{-1}$ (annual mean $\left.=234, \mathrm{SD}=105\right)$, respectively. Biodeposition rates peaked during mid-fall (April) and summer (January), with the lowest values calculated during winter (July-August). Both naturally sedimented and biodeposited particulate material contained mostly inorganic particles (Fig. 6). During the study period, the mean inorganic content of naturally sedimented material represented $458(\mathrm{SD}=211) \mathrm{g} \mathrm{DW}$ $\mathrm{m}^{-2} \mathrm{~d}^{-1}$, while that of $C$. chorus and $M$. chilensis biodeposits represented $212(\mathrm{SD}=85)$ and $184(\mathrm{SD}=$ 80) $\mathrm{g} \mathrm{DW} \mathrm{m}^{-2} \mathrm{~d}^{-1}$, respectively. The mean organic content of naturally sedimented material represented $95(\mathrm{SD}=67) \mathrm{g} \mathrm{DW} \mathrm{m}^{-2} \mathrm{~d}^{-1}$, while that of $C$. chorus and M. chilensis biodeposits was $59(\mathrm{SD}=28)$ and $49(\mathrm{SD}=$ 26) $\mathrm{g} \mathrm{DW} \mathrm{m}^{-2} \mathrm{~d}^{-1}$, respectively. General trends of temporal variability in the inorganic and organic fraction were similar to those observed in the total fraction. Thus, the correlation coefficients found between the 


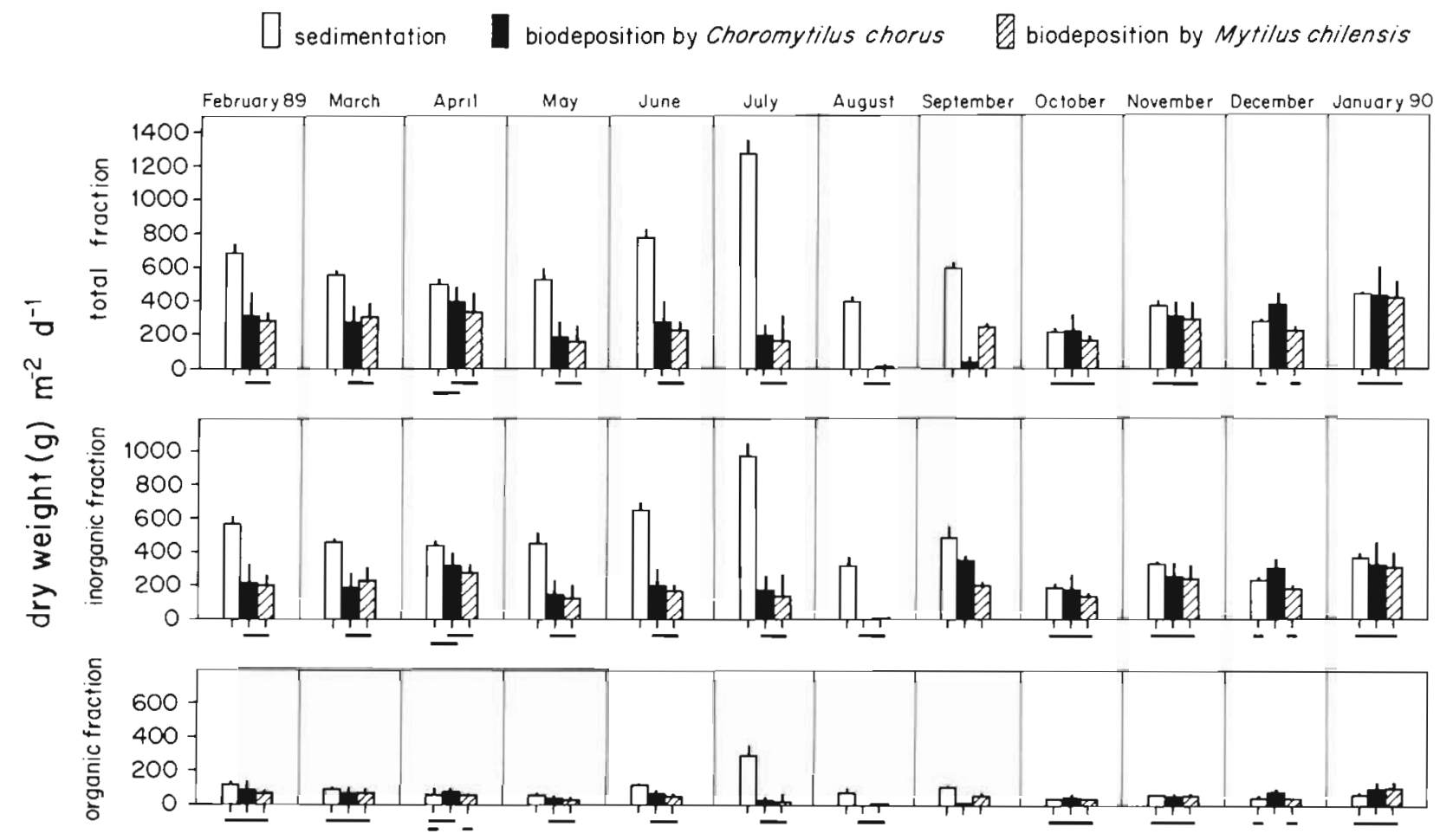

Fig. 6. Temporal variability in natural sedimentation and biodeposition of Choromytilus chorus and Mytilus chilensis at the study site (ca $4 \mathrm{~m}$ deep) in 1989 and 1990. Values are means +1 SD; horizontal lines connect values that were not significantly different

$\square$ sedimentation $\square$ biodeposition by Choromytilus chorus biodeposition by Mytilus chilensis
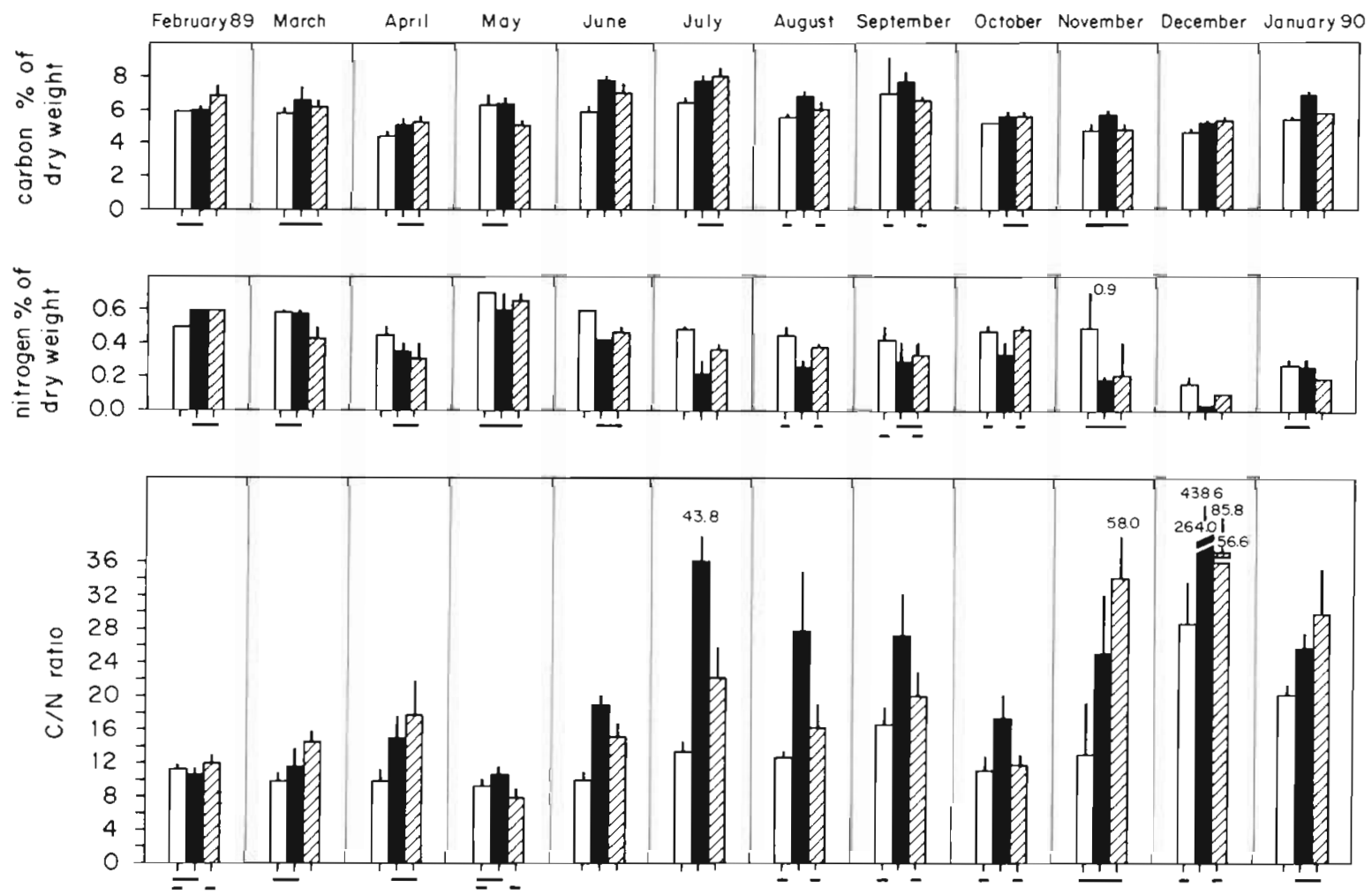

Fig. 7. Temporal variability in organic carbon, organic nitrogen and $\mathrm{C} / \mathrm{N}$ ratios in naturally sedimented particles and biodeposits of Choromytilus chorus and Mytilus chilensis at the study site (ca $4 \mathrm{~m}$ deep) in 1989 and 1990. Values are means + 1 SD; horizontal lines connect values that were not significantly different 
temporal variability of the total fraction and that of the inorganic and organic fractions were highly significant $\left(\mathrm{R}^{2}=0.86\right.$ to 0.99$)$.

Amounts of organic carbon and organic nitrogen in the naturally sedimented material and mussel biodeposits, expressed as \% dry weight, are shown in Fig. 7. In general, the temporal variability in these percentages did not display any seasonal trends such as those observed in the total and inorganic fractions of the naturally sedimented material and mussel biodeposits (compare Figs. 6 and 7). Annual mean organic carbon and organic nitrogen contents in naturally sedimented material were $5.5 \%(\mathrm{SD}=0.8 \%) \mathrm{and}$ $0.5 \%(\mathrm{SD}=0.1 \%)$, respectively. Annually, Choromytilus chorus biodeposits averaged $6.4 \%(\mathrm{SD}=1.1 \%)$ and $0.3 \%$ ( $\mathrm{SD}=0.2 \%$ ) organic carbon and nitrogen, respectively, while Mytilus chilensis biodeposits averaged $6 \%(\mathrm{SD}=1.0 \%)$ and $0.4 \%(\mathrm{SD}=0.2 \%)$ for organic carbon and nitrogen. Fig. 7 also shows that $\mathrm{C} / \mathrm{N}$ ratios in mussel biodeposits were more variable than those in sedimented material, and that generally, those in mussel biodeposits were higher. Thus, the annual mean $\mathrm{C} / \mathrm{N}$ ratio was $14(\mathrm{SD}=5.6)$ for naturally sedimented material, as compared with 41 ( $\mathrm{SD}=70.8)$ and $21(\mathrm{SD}=13.4)$ for biodeposits of $C$. chorus and $M$. chilensis, respectively.

\section{DISCUSSION}

Mussel biodeposits were quantitatively important in the particulate sedimentation of the Queule River Estuary during all months except August. During the period October to January, biodeposition rates were similar to natural sedimentation rates. The highest rates of natural sedimentation in the Queule River Estuary occurred during winter, most likely because rainfall, river flow and land runoff are higher during that period. This would also explain why the highest seston concentrations were registered during June-August, especially for the inorganic fraction during low tide.

Natural sedimentation rates at the study site (up to $1269 \mathrm{~g} \mathrm{DW} \mathrm{m}^{-2} \mathrm{~d}^{-1}$ ) were higher than those reported for other coastal areas. Maximum values of sedimentation (expressed in $\mathrm{g} \mathrm{DW} \mathrm{m} \mathrm{m}^{-2} \mathrm{~d}^{-1}$ ) were: 72 in Cook Inlet, Alaska (Chester \& Larrance 1981); 37 in a Baltic area (Kautsky \& Evans 1987); 4 in a Norwegian fjord (Wassmann 1985); 74 in Narragansett Bay, USA (Oviatt \& Nixon 1975); and 500 in Canada (Stephens et al. 1967). The Queule River Estuary, however, is much shallower than the above areas in the Northern Hemisphere. Thus, sediment resuspension in the estuary may be especially influential, as has been shown for other shallow environments (e.g. Young 1971, Rhoads et al. 1975, Roman \& Tenore 1978). The biodeposition rates calculated for mussels in the Queule River Estuary were also higher than those reported for another mussel under similar experimental conditions (Kautsky \& Evans 1987)

Biodeposition rates of Choromytilus chorus and Mytilus chilensis followed a clear seasonal pattern, with lowest values during winter months. Positive relationships between biodeposition rates of bivalves and food concentrations have been reported in laboratory experiments. For example, Tenore \& Dunstan (1973a) showed that the biodeposition rates of Mytilus edulis, Crassostrea virginica and Mercenaria mercenaria increased logarithmically with increased food concentration. Tenore \& Dunstan (1973b) also found that, apart from food concentration, food quality is also important in influencing biodeposition rates of $C$. virginica. But mussel biodeposition in the Queule River Estuary did not coincide with peak periods of food concentrations (assessed by chlorophyll a variability). Instead, the steady decrease in biodeposition rates from autumn to winter, and the steady increase observed from winter to spring and summer, closely followed temporal variability in temperature and salinity of the water column. Navarro (1988) reported that low water salinities $(<18 \%$ ) produce negative physiological responses in Choromytilus chorus, such as decreased filtration rates and valve closure. Some of these effects probably also occur in Mytilus chilensis (Navarro pers. comm.), thus resulting in decreased biodeposition rates. Other bivalves, such as Anadara senilis and $M$. edulis, also show valve closure when affected by low-salinity waters (Djangmah et al. 1979, Widdows 1985). Thus, it seems probable that the low biodeposition rates of $C$. chorus and $M$. chilensis during winter months were related to the low water salinities of that period. In contrast, the highest biodeposition rates occurred during periods of higher water salinities as well as higher water temperatures. The latter factor has also been invoked to explain temporal variability in the biodeposition rates of other bivalves. For example, Tsuchiya (1980) and Kautsky \& Evans (1987) found that the lowest biodeposition rates of $M$. edulis occurred during the coldest months. Low biodeposition rates of oysters have been also shown to coincide with periods of low water temperatures (Loosanoff 1958, Haven \& Morales-Alamo 1966). Finally, the low biodeposition rates of $C$. chorus and $M$. chilensis during winter might have been related to the high concentration of inorganic seston in the water column. During that period, the inorganic seston (most likely silt and clay particles) represented more than $66 \%$ of the total particulate matter, whereas lower percentages were calculated during the months when the highest biodeposition occurred. Thus, the proportion of potential food in the water column may have 
affected biodeposition rates. As shown by Widdows et al. (1979) for the Lynher Estuary (England), a winter increase in total seston diluted the amount of food material available for $M$. edulis.

$\mathrm{C} / \mathrm{N}$ ratios have usually been analyzed to assess the nutritional values of, for example, food, bacteria and detritus (e.g. Russel-Hunter 1970, Parsons et al. 1977 , Kautsky \& Evans 1987). Also, C/N ratios have been used to analyze temporal variability in nitrogen content, such as that in aging detritus; however, this analysis must be carried out with caution, since increase in nitrogen content in aging detritus does not necessarily reflect accumulation of living microbial protein, but rather an increase in non-labile humic nitrogen (Odum et al. 1979, Rice 1982). Furthermore, microbial density on aging detritus is not necessarily accounted for by the detrital nitrogen content (Cammen 1980, Rice 1982). Nevertheless, comparisons of $\mathrm{C} / \mathrm{N}$ ratios between naturally sedimented particles and mussel biodeposits yield insights into the characteristics of both materials. At first glance, the high $\mathrm{C} / \mathrm{N}$ ratios in mussel biodeposits in the Queule River Estuary would suggest that Choromytilus chorus and Mytilus chilensis are highly efficient in food utilization. However, this suggestion may be rejected since during several months, no significant differences were found between these ratios and those of the naturally sedimented particles. This general similarity suggests that natural sedimentation may have been related to mussel biodeposits produced by natural (non-experimental) mussels shortly before the experiments. $\mathrm{C} / \mathrm{N}$ ratios, especially of the biodeposits, increased during spring. The high ratios during this period may have resulted from a lack of dissolved nutrients, due to nitrogen depletion caused by the spring phytoplankton peaks in the Queule River Estuary (Winter et al. 1984). Also, it can be hypothesized that nutritive compounds in the water column were easily digested by grazing zooplankton, whose peaks of abundance followed those of phytoplankton during spring.

The $\mathrm{C} / \mathrm{N}$ ratios of naturally sedimented particles in the Queule River Estuary were higher than those reported for other coastal areas. Thus, mean ratios as high as 20 to 28 were calculated at the study site, as compared with values as high as ca 12 in Cook Inlet, Alaska (Chester \& Larrance 1981), Narragansett Bay (Oviatt \& Nixon 1975), Sweden (Dahlbäck \& Gunnarsson 1981), and Norway (Wassmann 1983), or near 10 in a Baltic area (Kautsky \& Evans 1987). The shallower conditions of the area studied here may result in a higher proportion of organic matter derived from resuspended bottom sediments, land runoff, and/or detritus from aquatic macrophytes [mostly Scirpus californicus (Mey) Steud. and Juncus balticus (Willd.)], as compared to deeper areas in which the organic matter should be mainly derived from phytoplankton (i.e., lower $\mathrm{C} / \mathrm{N}$ ratios). As shown by several authors (e.g. Newell 1965, Harrison \& Mann 1975, Tenore 1975) fresh invertebrate biodeposits and plant detritus are characterized by high $\mathrm{C} / \mathrm{N}$ ratios (low nutritional value). In contrast, low $\mathrm{C} / \mathrm{N}$ ratios characterize material of high nutritional value, such as phytoplankton (e.g. Kautsky \& Evans 1987). Therefore, it is interesting to note that some of the lowest $\mathrm{C} / \mathrm{N}$ ratios observed for the naturally sedimented particles of the Queule River Estuary occurred during the longest phytoplankton peak, i.e., February to May (compare Figs. 4 and 7 ). The $\mathrm{C} / \mathrm{N}$ ratios of the mussel biodeposits studied here were also higher than those of Mytilus edulis biodeposits (Kautsky \& Evans 1987). This difference is probably related to the age of the material analyzed rather than to actual differences in nitrogen content. In the present study, the sedimented material was retrieved after $2 \mathrm{~d}$ in the field, while during the studies of Kautsky \& Evans (1987) and Oviatt \& Nixon (1975), for example, sedimented material was retrieved from collecting devices after 9 to $28 \mathrm{~d}$ and $1 \mathrm{mo}$, respectively. Some investigators have shown that the nitrogen content of detritus originating from some vascular plants (Harrison \& Mann 1975, Rice \& Tenore 1981, Rice 1982) and invertebrate faecal pellets (Newell 1965) increases with time. However, Frankerberg et al. (1967) showed that the nitrogen content of faecal pellets deposited by the burrowing shrimp Callianassa major decreased within a short time (i.e. 48 h), while Roy \& Poulet (1990) found that the $\mathrm{C} / \mathrm{N}$ ratio of aging copepod faecal pellets showed little temporal variation. Thus, a key question remains: does the nitrogen content of mussel biodeposits in the Queule River Estuary increase with time?

Current velocities of up to $45 \mathrm{~cm} \mathrm{~s}^{-1}$ have been measured in the bottom waters of the Queule River Estuary (author's unpubl. data). These values and the low resistance of mussel biodeposits to water flow in laboratory experiments (author's unpubl. data) lead one to expect that faecal pellets of Choromytilus chorus and Mytilus chilensis will not remain long on the bottom of this estuary without breaking down. Nevertheless, mussel biodeposition may play a significant role in the ecological dynamics of the estuary by allowing fine particles to accumulate, as has been discussed for other coastal areas (Haven \& Morales-Alamo 1968, 1972. Kautsky \& Evans 1987); in other words, the fine particles composing mussel biodeposits would not settle as individual particles in bottom areas where hydrodynamic factors do not favour their settlement. Thus, an increase in fine particle deposition decreases water turbidity by lowering the particle load in the water column. Furthermore, the effects may be more significant if the nutritive (nitrogen) content of faecal pellets 
increases over time compared with that of the naturally sedimented particles. In this case, mussel biodeposits would eventually change the chemical characteristics of the indigenous sediment, as has been suggested e.g. for the York River, in which the bottom receives a large supply of oyster biodeposits having a higher organic matter content than the bottom sediment (Haven \& Morales-Alamo 1966).

Acknowledgements. We thank Luis Filun (Universidad Austral de Chile), who carried out the diving work for this study. The manuscript benefited from critical readings by Drs Nils Kautsky (University of Stockholm, Sweden) and Jorge Navarro (Universidad Austral de Chile), and 2 anonymous reviewers. This study was carried out with the financial support of the Third World Academy of Sciences (Grant RG BC 88-30), the International Foundation for Science (Grant A/7033 ) and the Universidad Austral de Chile (DID, Project S 88-02).

\section{LITERATURE CITED}

Bennet, A. (1976). Conversion of in situ measurement of conductivity to salinity. Deep Sea Res. 23: 157-165

Bohle, B. (1972). Effects of adaptation to reduced salinity on filtration activity and growth of mussels (Mytilus edulis). J. exp. mar. Biol. Ecol. 10: 41-49

Cammen, L. M. (1980). The significance of microbial carbon in the nutrition of the deposit feeding polychaete Nereis succinea. Mar. Biol. 61 9-20

Chester, A. J., Larrance, J. D. (1981). Composition and vertical flux of organic matter in a large Alaskan estuary. Estuaries $4 \cdot 42-52$

Dahlbäck, B., Gunnarsson, L. Å. H. (1981). Sedimentation and sulfate reduction under a mussel culture. Mar Biol. 63: 269-275

Djangmah, J., Shumway, S. E., Devenport, J. (1979). The effects of fluctuating salinity on the behaviour of the West African blood clam, Anadara senilis, and on the osmotic pressure and ionic concentrations of the hemolymph. Mar. Biol. 50: 209-213

Frankenberg, D., Coles, S. L., Johannes, R. E. (1967). The potential trophic significance of Callianassa major fecal pellets. Limnol. Oceanogr. 12: 113-120

Hand, S. C., Stickle, W B. (1977). Effects of tidal fluctuations of salinity on pericardial fluid composition of the American oyster Crassostrea virginica. Mar. Biol. 42: 259-271

Harrison, P. G., Mann, K. H. (1975). Detritus formation from eelgrass (Zostera marina L.); the relative effects of fragmentation, leaching, and decay. Limnol. Oceanogr 20: 924-934

Haven, D. S., Morales-Alamo, R. (1966). Aspects of biodeposition by oyster and other invertebrate filter feeders. Limnol. Oceanogr. 11: 487-498

Haven, D. S., Morales-Alamo, R. (1968). Occurrence and transport of faecal pellets in suspension in a tidal estuary. Sedimentary Geol. 2: 141-151

Haven, D. S., Morales-Alamo, R. (1972). Biodeposition as a factor in sedimentation of five suspended solids in estuaries. Mem. geol. Soc. Am. 133: 121-130

Hawley, N. (1982). Settling velocity distribution of natural aggregates. J. geophys. Res. 87: 9489-9498
Kautsky, N., Evans, S. (1987). Role of biodeposition by Mytilus edulis in the circulation of matter and nutrients in a Baltic coastal ecosystem. Mar. Ecol. Prog. Ser. 38: 201-212

Kraeuter, J, N. (1976). Biodeposition by salt-marsh invertebrates. Mar. Biol. 35: 215-223

Loosanoff, V L. (1958). Some aspects of behaviour of oysters at different temperatures. Biol. Bull mar biol Lab., Woods Hole 114: $57-70$

Maucha, R. (1932). Hydrochemische Methoden in der Limnologie. Die Binnengewässer 12. E. Schweitzerbart'sche Verlagsbuchhandlung, Stuttgart

Moore, H. B. (1931). The muds of the Clyde Sea Area. III. Chemical and physical conditions; rate and nature of sedimentation, and fauna. J. mar. biol. Ass. U.K. 17 : $325-358$

Navarro, J. M. (1988). The effects of salinity on the physiological ecology of Choromytilus chorus (Molina, 1782) (Bivalvia: Mytilidae). J. exp. mar. Biol. Ecol. 122: 19-33

Newell, R. (1965). The role of detritus in the nutrition of two marine deposit-feeders, the prosobranch Hydrobia ulvae and the bivalve Macoma balthica. Proc. zool. Soc. Lond, 144: $25-45$

Odum, W. E., Kirk, P. W., Zieman, J. C. (1979). Non-protein nitrogen compounds associated with particles of vascular plant detritus. Oikos 32: 363-367

Oviatt, C. A., Nixon, S. W. (1975). Sediment resuspension and deposition in Narragansett Bay. Estuar. coast. mar Sci. 3: 201-217

Parsons, T. R., Takahashi, M., Hargrave, B. (1977). Biological oceanographic processes, 2nd edn. Pergamon Press, Oxford

Rhoads, D. C., Tenore, K., Browne, M. (1975). The role of resuspended bottom mud in nutrient cycles of shallow embayments. In: Cronin, L. E. (ed.) Estuarine research, Vol. I. Academic Press, New York, p. 563-579

Rice, D. L. (1982). The detritus nitrogen problem: new observations and perspectives from organic geochemistry. Mar. Ecol. Prog. Ser. 9: 153-162

Rice, D. L., Tenore, K. R. (1981). Dynamics of carbon and nitrogen during the decomposition of detritus derived from estuarine macrophytes. Estuar coast. Shelf Sci. 13: $681-690$

Riehm, V., Ulrich, B. (1954). Quantitative kolorimetrische Bestimmung der organischen Substanz im Boden. Landwirtsch. Forsch. 6: 173-176

Roman, M. R., Tenore, K. R. (1978). Tidal resuspension in Buzzards Bay, Massachusetts. I. Seasonal changes in a tidal resuspension of organic carbon and chlorophyll a. Estuar. coast. mar Sci. 6: 37-46

Roy, S., Poulet, S. A. (1990). Laboratory study of the chemical composition of aging copepod fecal material. J. exp. mar. Biol. Ecol. 135: 3-18

Russell-Hunter, W D. (1970). Aquatic productivity. Macmillan, New York

Schlichting, E., Blume, H. (1966). Boderkkundliches Praktikum Paul Parey, Hamburg

Shumway, S. E. (1977). The effect of fluctuating salinity on the tissue water content of eight species of bivalve molluscs. J. comp. Physiol. 116: 269-285

Smaal, A. C., Verhagen, J. H. G., Coosen, J., Haas, H. A. (1986). Interaction between seston quantity and quality and benthic suspension feeders in the Oosterschelde. The Netherlands. Ophelia 26: 385-399

Stephens, K., Sheldon, R. W., Parsons, T R. (1967). Seasonal variations in the availability of food for benthos in a coastal environment. Ecology 48: 852-855

Strickland, J. D. H., Parsons, T R. (1972). A practical hand- 
book of seawater analysis. Bull. Fish. Res. Bd Can. 167. $1-310$

Tenore, K. R. (1975). Detrital utilization by the polychaete, Capitella capitata. J. mar. Res. 33: 261-274

Tenore, K. R., Dunstan, W. M. (1973a). Comparison of feeding and biodeposition of three bivalves at different food levels. Mar Biol. 21: 190-195

Tenore, K. R., Dunstan, W. M. (1973b). Comparison of rates of feeding and biodeposition of the American oyster, Crassostrea virginica Gmelin, fed different species of phytoplankton. J. exp. mar. Biol. Ecol. 12: 19-26

Tsuchiya, M. (1980). Biodeposit production by the mussel Mytilus edulis L. on rocky shores. J. exp. mar. Biol. Ecol. 47: 203-222

Wassmann, P. (1983). Sedimentation of organic and inorganic particulate material in Lindåspollene, a stratified, landlocked fjord in western Norway. Mar. Ecol. Prog. Ser. 13: $237-248$

This article was presented by J. E. Winter, Valdivia, Chile
Wassmann, P. (1985). Sedimentation of particulate material in two shallow, land-locked fjords in western Norway. Sarsia $70: 317-331$

Widdows, J. (1985). The effects of fluctuating and abrupt change in salinity on the performance of Mytilus edulis. In: Gray, J. S., Christiansen, M. E. (eds.) Marine biology of polar regions and effects of stress on marine organisms. Wiley Interscience, New York, p. 555-566

Widdows, J., Fieth, P., Worrall, C. M. (1979). Relationship between seston, available food and feeding activity in the common mussel Mytilus edulis. Mar. Biol. 50: 195-207

Winter, J., Toro, J., Navarro, J., Valenzela, G., Chaparro, O (1984). Recent developments status and prospects of molluscan aquaculture on Pacific coast of South America. Aquaculture 39: 95-134

Young, D. K. (1971). Effects of infauna on the sediment and seston of subtidal environment. Vie Milieu (Suppl.) 22: $557-571$

Manuscript first received: November 19, 1990 Revised version accepted: February 12, 1992 